УДК 618.11-006.6-073.48

\title{
В.В. Бойко ${ }^{1}$ К.В. Харченко ${ }^{2,3}$, О.П. Манжура ${ }^{2,3}$, І.Ю. Карачарова РОЛЬ СОНОГРАФІЇ У РАННЬОМУ ВИЯВЛЕННІ РЕЦИДИВУ РАКУ ЯЕЧНИКІВ
}

\author{
${ }^{1}$ ДУ «Інститут загальної та невідкладної хірургії імені В.Т. Зайцева НАМН України», м. Харків \\ ${ }^{2}$ Київський міський клінічний онкологічний центр \\ ${ }^{3}$ Національний медичний університет імені О.О. Богомольця, м. Київ
}

\begin{abstract}
Резюме. Рецидиви епітеліального раку яєчників розвиваються в $60 \%$ спостережень. Особливості клінічного перебігу вкрай ускладнюють вивчення механізмів розвитку рецидивів, можливості своєчасного виявлення прогресування захворювання і визначення оптимальної тактики лікування пацієнтів. Таким чином, проблема рецидивів раку яєчників потребує розробки надійної ранньої діагностики, моніторингу та лікування хворих
\end{abstract}

Вступ. У структурі жіночої онкологічної захворюваності в Україні рак яєчників (РЯ) стоїть на 7-му місці і становить 4,9\%, а в структурі смертності на 5-му - 6,3\%. Ще одним важливим статистичним показником є летальність на першому році $з$ моменту встановлення діагнозу $27,9 \%$ [3].

Проблема раннього виявлення рецидивів РЯ i їх лікування - одна 3 найскладніших у практичній онкогінекології. Труднощі раннього виявлення рецидивних пухлин пов'язані 3 порушенням топографо-анатомічних взаємовідносин органів малого таза, спайковим процесом після перенесеного хірургічного лікування, малим розміром пухлини, а також відсутністю виражених клінічних проявів захворювання $[1,2]$. Симптоми рецидиву РЯ, виявлені інструментальними методами, можуть бути неспецифічними: рубцева тканина після раніше перенесеного оперативного втручання або постпроменевий фіброз можуть імітувати рецидив пухлини. Своєчасна діагностика i терапія рецидивів РЯ сприяє збільшенню тривалості життя хворих і суттєво покращує іiі якість $[4,5]$.

Контрольні фізикальні огляди пацієнтів згідно $з$ графіком диспансерного спостереження, дослідження пухлинних маркерів - СА-125 і НЕ-4 проводяться лікарями при моніторингу хворих на рак яєчників після завершення спеціального лікування. Однак їх діагностична цінність не $\epsilon$ повною. Активно вивчається роль УЗД, комп'ютерної томографії (КТ) і магнітно-резонансної томографії (МРТ) при спостереженні даної групи пацієнтів [5]. В одному з досліджень, проведеному RDOG (Radiology Diagnostic Oncology Group), порівнювалася ефективність всіх трьох методів візуалізації при моніторингу пацієнтів на рак яєчників. УЗД $є$ важливим інструментом у виявленні та оцінці характеру змін, але має свої обмеження, а також $є$ апаратозалежним методом. КТ і МРТ (iз застосуванням в/в контрастування) більш точні та специфічні в цьому аспекті, особливо якщо мова йде про піддіафрагмальні ураження і оцінку дрібних внутрішньопечінкових змін. Метастатич- даним видом пухлин. У роботі проведений аналіз результатів діагностичних критеріїв обстеження хворих на рецидив раку яєчників. Встановлено, що чутливість ультразвукового методу діагностики рецидивів становить $88,1 \%$, специфічність - 75,5\%, точність - $82,5 \%$.

Ключові слова: діагностика рецидиву раку яєчників, УЗД у діагностиці рецидиву.

не ураження лімфатичних вузлів розміром менше 1 см достовірно визначаються при КТ і МРТ дослідженнях із внутрішньовенним контрастуванням. Однак ці методи відрізняються високою вартістю і також слід зауважити, що подібною апаратурою оснащені далеко не всі клініки, у зв'язку з чим використання цих діагностичних методик як моніторингу досить обмежене [6, 11, 12]. У зв'язку з цим, останнім часом у літературі з'являється все більше повідомлень про використання сонографії як діагностичного методу, який багаторазово відтворюється і безпечний, що дуже важливо при необхідності постійного динамічного моніторингу протягом короткого часу.

Ехографічне обстеження згідно з сучасними уявленнями має найбільшу ефективність у діагностиці локальних рецидивів РЯ в порожнині малого таза, особливо в комплексі з допплерівським картуванням (ДК). Поєднання сірої шкали Врежиму і ДК має низку важливих особливостей, а саме: дозволяє візуалізувати мінімальний пухлинний осередок, його структуру, конфігурацію, особливості кровотоку (значущі характеристики пухлинного процесу для визначення подальшої тактики лікування) [10]. У цьому аспекті в літературі з'являються дані про використання ультразвукового дослідження для визначення поширеності пухлинного процесу. Так, Savelli et al. канцероматоз був описаний як вузлуваті гіпоехогенні утвори по ходу очеревини, а в останніх проспективних багатоцентрових дослідженнях автори повідомляють, що ультразвук дуже вірогідно здатний виявити метастатичні зміни в куксі сальника [14].

При цьому слід зазначити, що можливості трансабдомінального УЗД для виявлення рецидиву пухлини в малому тазі часто обмежені в пацієнток, яким виконана радикальна гістеректомія. У даному випадку, адекватно досліджувати куксу піхви досить тяжко через їі невеликий розмір і анатомічне розташування. Крім того, післяопераційний рубець може змінювати картину при проведенні дослідження. Використання трансвагінального УЗД у моніторингу даної групи хворих $є$ 
обов'язковим методом у комбінації з трансабдомінальним оглядом, який дозволяє виявити невеликі прикуксові зміни навіть коли результати бімануального огляду були негативними $[9,13]$.

Таким чином, поряд із визначенням онкомаркерів, широке використання в онкології ультразвукового дослідження стало рутинним методом обстеження, завдяки достовірності отриманих результатів, неінвазивності, доступності, безпеки і можливості неодноразового застосування $[4,7,8]$.

Мета дослідження. Визначити роль соногpaфiï в діагностиці виникнення рецидиву раку яєчників для підвищення рівня ранньої його діагностики.

Матеріал і методи. Дослідження грунтується на ретроспективному вивченні амбулаторних карт 120 хворих, які були обстежені і проліковані 3 приводу РЯ в Київському міському клінічному онкологічному центрі (КМКОЦ) за період із 2012 по 2015 рр. Всім пацієнтам у ході первинного лікування проведено хірургічне втручання: пангістеректомія I типу з оментектомією в обсязі оптимальної циторедукціі. Як ад'ювантне лікування пацієнти отримували поліхіміотерапію за схемами САР або ТР. Пацієнти з розповсюдженою формою захворювання - 3 III стадією, склали найбільшу групу - (72,5 \%) 87 осіб. Решта осіб мали II стадію РЯ за FIGO - 33 обстежені (27,5 \%). 3 метою репрезентативності дослідження, ми не включали в нього пацієнтів із IV стадією процесу. Переважним гістологічним варіантом були серозні аденокарциноми, на частку яких припало (79,2 \%) спостережень - 95 пацієнтів. Рідше визначалися муцинозні і світлоклітинні пухлини 18 осіб(15,0 \%) і 7 випадків (5,8 \%) відповідно.

У всіх пацієнтів після проведення комбінованого лікування досягнута клінічна ремісія - при комплексному обстеженні (контрольних КТ або МРТ органів черевної порожнини та малого таза, рентгенографії органів грудної клітки, дослідження рівня онкомаркерів) даних про наявність об'ємного утворення отримано не було. При досягненні стабілізації процесу пацієнти переходили на диспансерний нагляд і проходили регулярні огляди відповідно до встановленого графіка.

При підозрі на рецидив хвороби в необхідний мінімум обстежень входили наступні: огляд гінеколога, аналіз крові на онкомаркер СА-125 і HE-4, УЗД черевної порожнини і малого таза 3 використанням ДК. Комплексне обстеження хворих із використанням імунологічного та ультразвукового методів дозволяє підвищити якість ранньої діагностики рецидивів раку яєчників, однак ехографія дає уявлення про топіку і уточнює ступінь поширеності процесу, розміри, зв'язок з прилеглими органами і тканинами, що має велике значення у визначенні подальшої тактики лікування.

Ультразвукове дослідження проводилося за стандартною методикою 3 використанням конвексного датчика 3,7 МГц і вагінального 7,5 МГц, за необхідності використовувалися ДК.
Основним завданням ультразвукового дослідження було виявлення патологічного утворення в порожнині малого таза або черевній порожнині і оцінка поширеності пухлинного процесу, проведення диференціальної діагностики рецидиву та непухлинних утворень малого таза. Мінімальний розмір метастазів, виявлених ультразвуковим методом у ділянці малого таза, склав 9 мм, за межами малого таза - 18 мм.

Пацієнтки з рецидивом раку яєчників практично не пред'являли скарг, специфічних для даного процесу, що часто ускладнювало діагностику. У більшості з них основною скаргою була підвищена втомлюваність, деякі пред'являли скарги на дискомфорт внизу живота.

Розрахунок ефективності проведеного діагностичного методу висвітлювалося у визначенні чутливості, специфічності, а також точності.

Результати дослідження та їх обговорення. Частота і характер рецидивів певною мірою залежали від характеристик первинної пухлини, а саме: стадія процесу і морфологічний варіант. У відібраній групі хворих рецидив був виявлений у 67 пацієнтів, що становило 55,8 \%. У 59 пацієнток цієї групи (49,2 \%) при проведенні УЗД ОМТ та ОЧП були виявлені зміни, характерні для рецидиву РЯ. Однак у восьми випадках $(6,7 \%)$ при УЗД ОМТ та ОЧП патології не виявлено: у хворих відзначалося підвищення онкомаркерів і за даними КТ ОМТ і ОЧП виявлені зміни, характерні для рецидиву хвороби. У 13 (16,3 \%) пацієнтів при диспансерному спостереженні і проведенні УЗД ОМТ та ОЧП виявлені ознаки, схожі на виникнення рецидиву. Однак при виконанні цим хворим КТ та/або МРТ з в/в контрастуванням і аналізу крові на онкомаркери, діагноз рецидиву РЯ не був підтверджений. У решти 40 пацієнтів рецидиву раку яєчників не виявлено ні клінічно, ні при проведенні інструментальних методів. Вони були відібрані нами (як контрольна група) для можливості визначення інформативності досліджуваного ультразвукового методу при використанні відомих методів статистичного аналізу.

Ультразвукове дослідження органів черевної порожнини було направлено на оцінку стану печінки, заочеревинних лімфовузлів, виявлення навіть мінімальної кількості рідини, а також канцероматозу очеревини.

Основною ехографічною ознакою рецидиву РЯ була наявність новоутворення в порожнині малого таза, яке було виявлено ізольовано або в поєднанні зі симптомами дисемінації по черевній порожнині і порожнині малого таза, а також метастатичними вогнищами. Частота виявлених ознак рецидиву РЯ представлена в таблиці.

У 52 (88,1 \%) спостереженнях рецидивні пухлини візуалізувалися у вигляді вузлового утворення, локалізованого в порожнині малого таза. При прогресуванні процесу, проростання пухлини в прилеглі органи і тканини їх межі ставали нечіткими. Найбільш часто дані пухлинні 
Таблиця

Ультразвукові ознаки рецидиву раку ясчників

\begin{tabular}{|c|c|c|}
\hline Локалізація процесу & \multicolumn{2}{|c|}{ Кількість випадків } \\
\cline { 2 - 3 } & абс. & 88,1 \\
\hline Пухлина в малому тазі & 52 & 69,5 \\
\hline Асцит & 41 & 22,0 \\
\hline Канцероматоз очеревини & 13 & 25,4 \\
\hline Збільшення парааортальных л/в & 15 & 18,6 \\
\hline Збільшення здухвинних л/в & 11 & 11,9 \\
\hline Метастази в печінці & 7 & 5,1 \\
\hline Рецидив у куксі сальника & 3 & \\
\hline
\end{tabular}

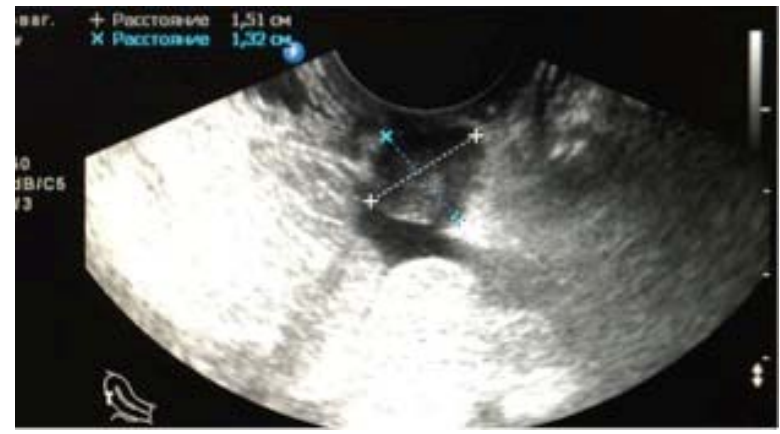

Рис. 1. Рецидив раку яєчників в порожнині малого таза у вигляді солідного утвору $41 \times 26 \times 34$ мм

утворення локалізувалися ззаду від кукси піхви i в прикультьовій зоні.

При оцінці ехоструктури рецидивних пухлинних вогнищ у порожнині малого таза нами були виділені наступні ультразвукові типи будови: солідний, солідно-кістозний, кістозний. Найбільш часто були виявлені солідні утворення - 33 випадки $(63,5$ \%), при цьому пухлина, зазвичай, мала округлу або неправильну форму, з нерівними, нечіткими горбистими контурами (рис. 1). При проведенні колірного і енергетичного картування в солідному компоненті визначалася неоваскуляризація. Рідше траплялися соліднокістозний тип - 12 випадків $(23,1 \%)$ і кістозний 7 випадків (13,4\%).

Контури утвору нечіткі, нерівні, вільна рідина в порожнині малого таза не визначалась. Рецидив у даної пацієнтки був виявлений через два роки і шість місяців після комбінованого лікування РЯ ІІс стадії.

Треба відзначити, що орієнтація на характеристику контурів рецидивного утворення не повинна стати провідною для постановки діагнозу рецидиву РЯ. Будь-яка зміна в малому тазі по ходу динамічного моніторингу має бути підставою для висловлення підозри щодо рецидиву РЯ.

У $13(22,0 \%)$ випадках спостерігалось інфільтративне поширення пухлини по малому тазу. По контуру очеревини візуалізувалися солідні утворення зниженої ехогенності. Листки очеревини являли собою гіпоехогенну структуру з васкуляризацією і відсутністю перистальтичних рухів. При підозрі на канцероматоз або залучення в процес брижі тонкої кишки визначалося відчуття «фіксованості» петель кишечнику.

Розвиток метастазів по очеревині майже завжди супроводжувався появою асцитичної рідини, яка візуалізувалася як ехонегативна зона, розташована під передньою черевною стінкою та по флангах. Це було відзначено у 69,5 \% хворих. Невеликий випіт визначався в дугласовому просторі і підпечінковій ділянці та латеральних каналів. Вільна рідина в черевній порожнині була хорошим контрастним середовищем для виявлення метастазів по очеревині розмірами від 5 мм. Дані зміни по парієтальній очеревині і передній черевній стінці добре виявлялися поверхневим датчиком 7,5 МГц.

Інтерпретування наявності вільної рідини в порожнині малого таза залишається дискутабельним питанням діагностики рецидиву раку яєчників. Наявність невеликої кількості рідини в порожнині малого таза до 20 мл може спостерігатися у хворих і в стані ремісії досить тривалий час. Ми спостерігаємо цю картину в деяких пацієнток, які перебувають на диспансерному спостереженні. Ключовим моментом є те, що відсутність вільної рідини у них не спостерігалась ні при жодному УЗД у стані ремісії. При цьому не відзначалося і підвищення онкомаркера. Однак при виявленні навіть дуже невеликої кількості рідини в порожнині малого таза, у разі відсутності останньої при попередньому дослідженні, ми проводили дослідження крові на онкомаркер СА125 і НЕ-4. За відсутності підвищення онкомаркера в даному випадку, проводилося контрольне УЗД ОЧП і ОМТ через місяць. При збереженні вільної рідини в порожнині малого таза виконувалося КТ або МРТ з внутрішньовенним контрастуванням. За такого перебігу хвороби рецидив за даними КТ було виявлено у чотирьох пацієнток (наявність канцероматозу за даними КТ).

Однією з частих локалізацій рецидиву раку яєчників є лімфовузли таза і парааортальної зони. Ми спостерігали збільшення даних груп лімфовузлів у 18,6 \% і 25,4 \% випадків відповідно. Часто труднощі візуалізації даних рецидивів пов'язані 3 наявністю пневматозу кишечнику. У цих випадках ми проводили контрольне УЗД ОМТ, ОЧП після ретельної підготовки пацієнтки. Лімфовузли визна- 


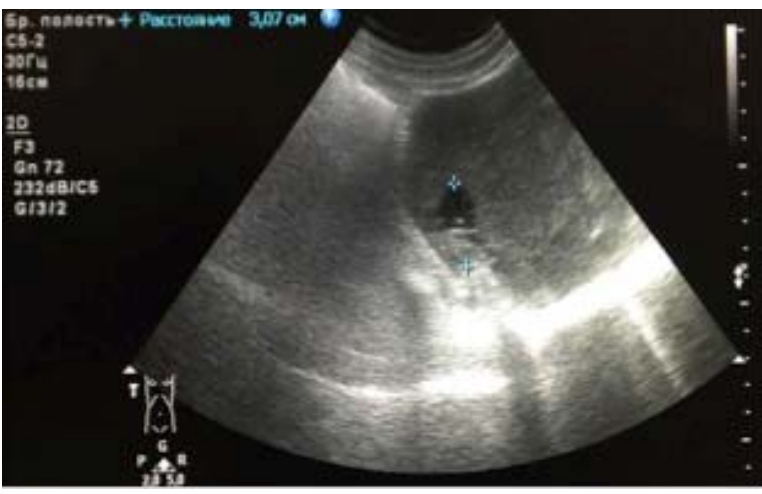

Рис. 2. Метастатичні зміни в печінці, межа VI-VII сегментів

чалися у вигляді округлих утворень зниженої або середньої ехогенності розміром не менше $1 \mathrm{~cm}$.

У $11,9 \%$ спостережень у пацієнтів були виявлені метастази в печінці. Дані новоутворення оцінювали як утворення гетерогенної структури будь-якого розміру 3 нерівним нечітким контуром, часто з підвищеною васкуляризацією, або вогнищ, що нагадують за структурою первинну пухлину (рис. 2).

Рецидив у куксі сальника спостерігався у 5,1 \% хворих і був виявлений при трансабдомінальної сонографії, локалізувався в ділянці селезінкового кута товстої кишки між парієтальною очеревиною передньої черевної стінки і петлями кишечнику у вигляді рясно васкуляризованої ділянки солідної будови (рис. 3).

У ряді випадків визначалися поєднані ураження: найбільш часто - утворення в порожнині малого таза і асцит (22 випадки (37,3 \%)), або утворення в порожнині малого таза і метастази в заочеревинних лімфовузлах -13 випадків $(22,0$ \%). Відзначалися і множинні поєднання 12 випадків (20,3\%).

При оцінці васкуляризації рецидивних пухлин у режимі ДК кровотік реєструвався не у всіх спостереженнях. Значна частина рецидивних пухлинних вогнищ мали підвищену васкуляризацію 49 випадків (72,9 \%). Використання допплерівських методик дещо покращувало диференційну діагностику пухлинних процесів від прикультьових утворень запального характеру.

Чутливість ультразвукового методу при діагностиці рецидивів у нашому спостереженні становила $88,1 \%$, специфічність - 75,5 \%, точність $82,5 \%$.

Таким чином, будучи класичним методом «моніторингової» діагностики, сонографія дає можливість виявити досить ранні ознаки не тільки осередкового варіанта рецидиву в малому тазі, а й визначити поширеність пухлинного процесу 3 високим показником точності. Саме в такому контексті ми і розглядаємо сучасну ехографію в проблемі діагностики рецидивів РЯ.

\section{Висновки}

1. Основними ультразвуковими ознаками рецидиву раку яєчників $є$ : утворення в порожнині малого таза (88,1 \%), асцит $(69,5$ \%), лімфадено-

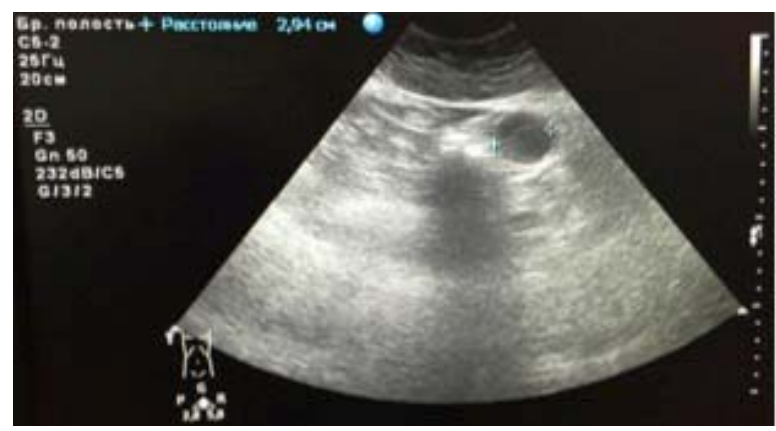

Рис. 3. Метастаз у куксі сальника, розміром 29,4мм

патія заочеревинного простору (44,1%), канцероматоз очеревини $(22,0 \%)$.

2. Ультрасонографія дозволяє чітко візуалізувати рецидив пухлини розміром від 5 мм, даючи можливість виявити повернення хвороби до доклінічної стадії.

3. У разі невідповідності даних ультразвукового дослідження з клінічною картиною або підвищенням онкомаркера необхідно виконувати комп'ютерну томографію або магнітнорезонансну томографію 3 в/в контрастуванням для уточнення характеру процесу.

4. Інформативність при ультразвуковому дослідженні рецидивів раку яєчників у нашому дослідженні становила: чутливість - 88,1 \%, специфічність - 75,5\%, точність - 82,5\%.

\section{Література}

1. Жорданиа К.И. Некоторые аспекты диагностики и лечения рака яичников / К.И. Жорданиа // Русс. мед. ж. - 2003. - № 5. - С. 7-8.

2. Люстик А.В. Ультразвуковые и молекулярнобиологические критерии ранней диагностики рака яичников: автореф. дис. на соискание уч. ст. канд. мед. наук: 14.01.13., 14.01.12. / А.В. Люстик. - ФГБУ «РНЦРР» МЗ РФ. - М., 2012. - 22 c

3. Рак в Україні, 2014-2015. Захворюваність, смертність, показники діяльності онкологічної служби // Бюл. нац. канцер-реєстру України. -К., 2016. - С. 52

4. Стецюк Е.Л. Возможности ультразвукового исследования в диагностике рецидивов рака яичников / Е.Л. Стецюк // Мед. радиол. радиац. безопасность. 2008. - Т. 53, № 4. - С. 50-55.

5. Хачкурузов С.Г. УЗИ в гинекологии. Симптоматика, диагностические трудности и ошибки / С.Г. Хачкурузов. - ЭЛБИ-СПб., 2008. - С. 8-9.

6. Чекалова М.А. Значение использования УЗТ и ПЭТ при диагностике прогрессирования рака яичников / М.А. Чекалова // Сибир. онкол. ж. - 2008. - № 3. C. 63-64.

7. Diagnosis and staging of ovarian cancer: comparative values of Doppler and conventional US, CT, and MR imaging correlated with surgery and histopathologic analysis: report of the radiology diagnostic oncology group / A.B. Kurtz, J.V. Tsimikas, C.M.C. Tempany [et al.] // Radiology. - 1999. - Vol. 212 (1). - P. 19-27.

8. Guidelines: recognition and initial management of ovarian cancer: summary of NICE guidance / C. Redman, S. Duffy, N. Bromham [et al.] // BMJ. - 2011. - Vol. 342. - P. 7804.

9. Improving strategies for diagnosing ovarian cancer: a summary of the international ovarian tumor analysis (IOTA) studies / J. Kaijser, T. Bourne, L. Valentin [et al.] // Ultrasound Obstet Gynaecol. - 2013. - Vol. 41 (1). - P. 9-20. 
10. Indeterminate ovarian mass at US: incremental value of second imaging test for characterization - meta- analysis and Bayesian analysis / K. Kinkel, Y. Lu, A. Mehdizade [et al.] //Radiology. - 2005. - Vol. 236. - P. 85-94.

11. Jelovac D. Recent Progress in the Diagnosis and Treatment of Ovarian Cancer / D. Jelovac, D.K. Armstrong // CA Cancer J. Clin. - 2011. - Vol. 3. - P. 183-203.

12. Role of ultrasound in characterization of ovarian masses / S. Hafeez, S. Sufian, M. Beg [et al.]// Asian Pac. J. Cancer Prevent. - 2013. - Vol. 14 (1). - P. 603-606.

13. Sensitivity and specificity of multimodal and ultrasound screening for ovarian cancer, and stage distribution of detected cancers: results of the prevalence screen of the UK collaborative trial of ovarian cancer screening (UKCTOCS) / U. Menon, A. Gentry-Maharaj, R. Hallett [et al.] // Lancet Oncol. - 2009. - Vol. 10 (4). P. 327-340.

14. Ultrasound and color power Doppler in the detection of metastatic omentum: a prospective study / A.C. Testa, M. Ludovisi, L. Savelli [et al.] // Ultrasound Obstet Gynecol. - 2006. - Vol. 27. - P. 65-70.

\title{
РОЛЬ СОНОГРАФИИ В РАННЕМ ВЫЯВЛЕНИИ РЕЦИДИВА РАКА ЯИЧНИКОВ
}

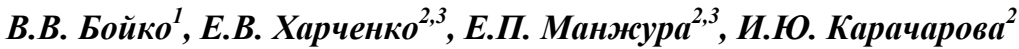

Резюме. Рецидивы эпителиального рака яичников развиваются в 60 \% наблюдений. Особенности клинического течения крайне затрудняют изучение механизмов развития рецидивов, возможности своевременного выявления прогрессирования заболевания и определения оптимальной тактики лечения пациентов. Таким образом, проблема рецидивов рака яичников требует разработки надежной ранней диагностики, мониторинга и лечения больных данным видом опухолей. В работе проведен анализ результатов диагностических критериев при обследовании больных рецидивом рака яичников. Установлено, что чувствительность ультразвукового метода при диагностике рецидивов составляет $88,1 \%$, специфичность $-75,5 \%$, точность $-82,5 \%$.

Ключевые слова: диагностика рецидива рака яичников, УЗИ в диагностике рецидива.

\section{ROLE OF SONOGRAPHY IN THE EARLY DETECTION OF OVARIAN CANCER RELAPSE}

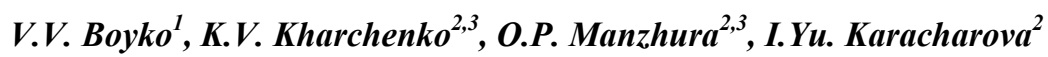

Abstract. Relapses of epithelial ovarian cancer developed in $60 \%$ of cases. Clinical course makes it extremely difficult to study the mechanisms of relapse, the possibility of early detection of disease progression and determine the optimal treatment strategy of patients. Thus, the problem of relapse of ovarian cancer requires the development of a reliable early diagnosis, monitoring and treatment of patients with this type of tumor. This paper presents the results of diagnostic criteria when examining patients with relapsed ovarian cancer. It was established that the sensitivity of ultrasound method in the diagnosis of recurrence is $88.1 \%$, specificity $-75,5 \%$, accuracy $-82,5 \%$.

Key words: diagnosis of ovarian cancer recurrence, ultrasound in the diagnosis of recurrence.

${ }^{1}$ State institution «V.T. Zaytsev Institute of General and Emergency Surgery of NAMS of Ukraine» (Kharkiv)

${ }^{2}$ City Clinical Cancer Center (Kyiv)

${ }^{3}$ Bogomolets National Medical University, Oncology Department (Kyiv)

Рецензент - проф. В.П. Польовий

Buk. Med. Herald. - 2016. - Vol. 20, № 3 (79). - P. 18-22

Надійшла до редакції 27.04.2016 року

(C) В.В. Бойко, К.В. Харченко, О.П. Манжура, І.Ю. Карачарова, 2016 